\title{
Lyric Vision: An Introduction
}

\author{
Anastasia-Erasmia Peponi
}

'Do I paint it natural, Susie, so you think how it looks?' Dickinson, a defiant and uncanny poet of the modern era, referring to her own verbal skills. Quintessentially lyric, especially if one admits that lyric thrives in the gaps and breaches of conventional generic taxonomies, Dickinson was repeatedly testing the boundaries between the verbal and the visual in her own recalcitrant manner. Neither the first nor the last among modern poets to approach such issues, the inventiveness and unpredictability of Dickinson's experimentations are yet particularly telling instances of the way in which modern lyric has always reached out for the world of the visual when exploring the flexibility of its own frontiers.

Was this the case in ancient lyric poetry as well? We will probably never learn in what context Simonides of Keos, one of the nine lyric poets of the Alexandrian canon, articulated the famous statement attributed to him by Plutarch: 'Simonides calls painting silent poetry and poetry painting that speaks.' ${ }^{2}$ It is worth tackling at some length this sweeping utterance about the relationship between the verbal and the visual as it seems to touch upon key aspects of the ways lyric poetry engaged with vision and visuality in antiquity. Before doing so, however, I would like to bring up - if briefly - two sets of broader considerations regarding ancient lyric poetry and its visual demeanor.

The first set of considerations relates to broader questions pertaining to the role of lyric poetry in the development of visual sensibilities and practices in Greek cultures. To what extent can the various Greek lyric genres, with their powerful soundscapes generated by verbal or musical components, be considered an important part of Greek discourses about the visual? Indeed, the rich area of lyric production (understood here inclusively, as the totality of melic, elegiac and iambic genres) did reflect, shape, and interact with dominant modalities of viewing in Greek cultures. To put it in a different way, lyric production created its own diverse and manifold spectatorships.

1 Dickinson (1958) 85.

2 De glor. Ath. $346 \mathrm{f}$.

(C) ANASTASIA-ERASMIA PEPONI, 2016 | DOI: 10.1163/9789004314849_002

This is an open access chapter distributed under the terms of the Creative Commons Attribution-

Noncommercial 3.0 Unported (CC-BY-NC 3.0) License. 
By using the term spectatorship I refer to at least three viewing practices associated with Greek lyric poetry.

First of all, I refer to the wide range of its actual performative aspects, an essential part of which was meant to address sight in its purely sensory impact. One should include here not only the evidently visual aspect of Greek chorality, namely the dance component in all of its many instantiations, but also the visual force of solo performances, for instance the kitharodic, where the performer's apparel along with his kinetic apparatus created a powerful and affective optical nexus. ${ }^{3}$ In this broader category I would also include the public display of inscribed poetry, the various genres of which were integral parts of lyric traditions. In Greek cultures inscribed poetry was conceptualized as a distinct mode of performance that engineered its own spectatorships. ${ }^{4}$

Next, I refer to the various ways in which lyric genres responded and contributed to, or even generated their own, modes of visual imagination. How cultures shape and manipulate imagination is an essential part of their visual sensibilities: the various ways in which Greek lyric poets handled visual representation revealed exciting potentials for imaginary envisioning. From the wide range of verbal representations of colors, hues, shades of light and darkness, shapes, objects, faces, bodies, to larger-scale interior settings and all sorts of topographies and landscapes, lyric poetry created, within its verbal fabric, a visual world to be accessed and enjoyed through intense imaginative activity.

Finally, I refer to the critical junction of vision, on the one hand, and visualization, on the other, in other words to the intersection-and indeed interaction - of what can actually be seen with what can be visually imagined. The juxtaposition of, or osmosis between, these two visual modalities, vision and visualization, is of paramount importance for our understanding of Greek visuality. Lyric poets played a key role in promoting ways of bringing them together. In fact, strategies of handling vision and visualization may illuminate selective affinities among seemingly disparate areas such as dramatic productions, lyric performances, and ekphrastic discourses.

That is to say that the Athenian theater was not just the locus par excellence for seeing but, perhaps even more importantly, it was where actual seeing, as a sensory activity, was mixed with modes of visualizing the unseeable. The muchdiscussed case of the messengers' speeches in tragedy, with their dense optical references inaccessible to the audience, is a typical but far from exclusive

3 On the visual perception of dance see Peponi (2015) 204-217 with further bibliography. On kitharôidia as spectacle see Power (2010) 11-27 and passim.

4 On various aspects of this issue see Svenbro (1993); Day (2010); LeVen (2014) 283-329. 
instance of this practice. Interestingly, techniques of apposing, correlating, and at times fusing actual and virtual vision are a quintessential part of the rhetoric we encounter in the oldest surviving sample of Greek choral lyric from the seventh century BC, Alcman's first Partheneion ( $P M G F$ 1). In a section of the partheneion that is densely packed with visual references, Alcman's chorus of young women refers to their chorus leaders in this way: 'Don't you see? This race horse / is Enetic; but the hair / of my cousin / Hagesichora has the bloom / of undefiled gold. / And that silver face of hers! / But why am I talking to you with full clarity? / Here she is: Hagesichora!' (vv. 50-57). ${ }^{5}$ Even if the simulated second-person addressee, who is urged to look at what the song describes, is the chorus members themselves addressing each other, there should be no question that the targeted and ultimate addressee of this animated rhetoric is the audience watching the choral performance. Yet the repeated encouragement to behold, and even more the rhetoric of admonition to look at details supposedly obvious and in front of one's eyes (for instance, the silvery face of Hagesichora) was in fact much more artful, especially if one takes into account not only the restrictions on optical access for an audience watching the performance but, even more, the time of the actual performance which, as has been repeatedly suggested, was probably before sunrise. More importantly, one realizes that these optical incentives are in flux as they are part of a continual flow of changing metaphors. In other words, a series of visual stimuli is indeed displayed in front of the audience's eyes, but it is mainly with their imaginative power that the audience can interpret and enjoy them, prompted by the intricate verbal nexus of the chorus' song. ${ }^{6}$

This deep-seated cultural practice of enriching the visual by emancipating it from actual sight while, at the same time, rhetorically appealing to this very sight, was significantly advanced by Greek lyric traditions in numerous ways. Once described this way, this practice helps us realize the existence of a common attitude towards visuality in verbal samples of very different provenance. It is because of this well-established cultural stance, for instance, that the ancient commentator Heraclitus could contend that Archilochus' poem impelling Glaucus to look at the threatening signs of a storm is part of an elaborate allegory. ${ }^{7}$ Regardless of whether or not these lines were meant

5 The translation here as in Peponi (2004) 297-298 and n. 3.

6 For an extensive discussion of the way visual perception operates in this poem along with a discussion of the relevant literature (including Calame's seminal work) see Peponi (2004). See more recently Budelmann (2013) 81-98, esp. 81-93.

7 Fr. 105 w. ap. Heraclit. All. 5·3. 
as an allegory by the poet himself, the speaker's urging that Glaukos look $(\not \circ p \alpha$, v. 1) as 'already waves are disturbing the deep sea and a cloud stands straight round about the heights of Gyrae, a sign of storm' is clearly yet another instantiation of a rhetorical appeal to pure sight designed to stir imaginary envisioning. ${ }^{8}$ The trope is still flourishing in ekphrastic literature of a much

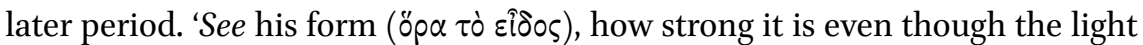
has gone from his eyes; see (öp $\alpha$ ) his downy beard, how it matches his age with that of his youthful slayer.' ${ }^{9}$ This is Philostratus the Elder, in the third century AD, encouraging his internal addressee, a ten-year-old boy, to look at details of a painting representing the death of Memnon. In the first book of his Imagines there are about two dozen instances where the verb ópâv is used as an admonition to his addressee to look at the parts of the painting the speaker is in the process of describing and interpreting. In ways not dissimilar to early lyric poetry, this intratextual viewer-Philostratus' constructed witness-functions as a trope, a way for the speaker to rouse and empower the visualizing potential of his readers' imagination.

The second set of questions relates to the political aspects of lyric visuality. Was there-or could there ever be-a politics of viewing in the case of archaic and classical lyric production? The question is prompted by compelling and influential suggestions, made over the last twenty years in classical scholarship. Such approaches usually focus on Athenian visual culture and more specifically on Athenian theater. 'The act of looking, central to any discussion of word and image,' Simon Goldhill wrote, 'must be comprehended in the broadest possible way as a culturally and historically specific performance, and if we are to understand how word and image are conceptualised in ancient democratic Athens, then the construction of the democratic subject as viewer is a necessary project.' ${ }^{\prime 10}$

Comprehending mentalities of viewing as generated and practiced within 'culturally and historically specific performance' entails performance genres originating from and fastened to a specific cultural and political environment, and this was indeed how classical Athenian drama, for instance, operated by and large. It is reasonable to think that when Euripides was composing his tragedies he was principally elaborating on or challenging Athenian modes of looking at a tragic production, while addressing visual sensibilities that had

\footnotetext{
8 Translation by Gerber (1999) 145. On this poem see recently Bowie (2009) 109-110.

9 Philostr. Imag.1.7.2; translation by Fairbanks (1931).

10 Goldhill (2000) 165 .
} 
been molded by the totality of Athenian democratic institutions. How he may have thought about the viewing practices and sensibilities of a Macedonian audience, if we ponder the possibility that he composed the Bacchae in the court of Archelaus with the prospect of a production in the area, is an intriguing question. ${ }^{11}$ In other words, should we think that an Athenian 'democratic subject as viewer' had its equivalent in a Macedonian 'monarchical subject as viewer'? What would monarchy and its institutions entail for an audience's visual psychology?

To return to our subject, the usefulness of such highly speculative questions is that they make one realize how challenging it is to conceive of a politics of viewing in the case of lyric genres, even though most of them employed significant visual components. Contrary to the fixity of Athenian drama, which was wholly centralized inasmuch as it was produced and originally meant to be consumed by Athenians (or by visitors joining an Athenian audience in an Athenian theater), a very considerable part of the archaic and classical lyric production was generally itinerant and centrifugal. ${ }^{12}$

This typical mobility of lyric production and performance complicates the relationship between the dynamics of spectatorship, on the one hand, and political structures, on the other. The plurality, diversity, and transformability of ancient lyric genres do not allow for an exhaustive discussion of this issue, yet a couple of examples can highlight different aspects of it. The political issues deriving from the programmatic transportability and adjustability of epinician poetry, along with some of their visual implications, have been addressed effectively in scholarship. ${ }^{13}$ Here I would like to offer examples from a different area. The New Musical scene, for instance, has primarily been discussed in connection with Athenian theatrical culture and as an emblematic case of its decaying democratic ideologies, as these were seen by certain aristocratic circles. ${ }^{14}$ Yet most influential representatives of the profoundly lyric new waves were composers and performers visiting democratic Athens from all over the Hellenic world. To single out only some representatives of this stylistically

11 On this possibility see for instance Seaford (1996) 184.

12 For different aspects of this issue see for instance Nagy (1990) 82-115, in regards to the 'panhellenization of song; Kowalzig (2007) in relation to choral rituals and locality; Hunter and Rutherford (2009) on travelling poets, with a focus on lyric poets in several excellent chapters; Rutherford (2013) in relation to the cultural practice of theoria, part of which was attached to lyric production and performance; LeVen (2014) esp. 134-148 on traveling poets in later classical lyric.

13 See for instance Kurke (1991); Athanassaki (2009); Morgan (2015).

14 See for instance Csapo (2004) 207-248. 
diverse but nevertheless consistently innovative group: Melanippides was from Melos, Philoxenus from Cythera, Timotheus from Miletus, Phrynis from Lesbos, Telestes from Selinous, and Polyidus from Selymbria. ${ }^{15}$ Even if we assume that the Athenian musical-and-theatrical scene along with its audiences created the ideal pool for musical advances and experimentations, it is still important to think about the many and quite different cultural and political environments that generated such musicians in the first place. What were the dynamics of spectatorship in their own, quite divergent, poleis? And did these in any way trigger such novel (as it turned out) musical impulses?

Questions regarding lyric production in relation to the political infrastructures of its consumption become even more complex if we take into account data indicating how welcomed the musical vanguard seems to have been in the monarchic environment of Macedonia. Unlike those with oligarchic inclinations in Athens who found all sorts of flaws in modernizing experimentations, for which they blamed democracy, the monarchic establishment in Macedonia sought to embrace them. The Macedonian hospitableness, not only to experimental tragedians such as Agathon and Euripides, but apparently to at least two lyric representatives of musical innovation as well (Melanippides and Timotheus) indicates that the political underpinnings of taste were malleable enough to allow for a smooth shift from a radical democracy to an ambitious monarchy. In other words, along with the traveling lyric poets and their audiovisual productions, the political dynamics of spectatorship could swerve in quite oblique ways. ${ }^{16}$

These two, briefly discussed, sets of considerations regarding the ways in which lyric production challenged, complicated, or contributed to visual sensibilities in Greek cultures, provide an illuminating context for a lengthier exploration of the famous Simonidean statement regarding the relationship between poetry and painting. The quotation, with nearly identical wording and unequivocal attribution to Simonides, appears twice in Plutarch's works. The authoritative style of the phrase, along with its symmetrical wording, fits nicely the profile of a poet who was indeed well known in antiquity for his broader intellectual allure, but it also encourages generalizing interpretations. According to the

15 For a geocultural mapping of lyric production in the archaic and classical periods see Driscoll et al. (2015).

16 For Melanippides in Macedonia see Sud. $\mu 454$ Adler. See also LeVen (2014) $115^{-118}$ for the problems of his identity. For Timotheus in Macedonia see for instance Plut. Mor. 177b and 334 b; on the possibility that he died there see Steph. Byz. $\mu 184$ Billerbeck. 
predominant approaches it is the totality of poetry, regardless of genre, that is said to be speaking painting. But was this Simonides' original intention? Or was the statement part of a poetic manifesto meant to explain his own lyric art?

Although we cannot exclude the possibility that Simonides' statement was meant to be heard as a sweeping pronouncement about poetry as a whole, such a formulation must have been elicited primarily by his own experience of, and experimentation with, the wide range of the poetry that he himself was composing, namely melic. Thus the phrase, uttered by one of the most sought-after and well-traveled lyric poets of the late archaic and early classical Greek world, is emblematic for the broader subject of this volume: The Look of Lyric, Greek Song and the Visual. Certainly, in the volume as a whole it will be clear that painting was far from the sole visual art with which Greek lyric poetry engaged. On the contrary, over the last years there has been some excellent work on the diverse channels through which lyric poetry, and especially choral song, addressed yet another visual art, sculpture, to mention just one other example. ${ }^{17}$ My focus on painting as an emblematic instance of lyric poetry's relationship with the visual is due to three factors: first, to the fascinating influence that the Simonidean statement exercised over the centuries; second, to the curious fact that scholarship tends to be oblivious of the lyric identity of its creator; and, third, to the fact that painting is the art that played a consistently decisive role in Greek critical thought throughout antiquity, whenever philosophers, critics, or poets commented on, or theorized, the verbal arts. This trend, conceivably originating with, or at least advanced by, the lyric poet Simonides can be traced in major authors, for instance Plato, Aristotle, Demetrius, Dionysius of Halicarnassus, and Longinus-not to mention Horace's notorious and perhaps already clichéd ut pictura poesis in his Ars Poetica.

Whether or not the two different but equally thought-provoking contexts in which Plutarch quotes the Simonidean phrase are close to the original context in which the poet might have employed it will remain unknown, yet both instances are suggestive of the complexity that may have underlain the statement's deceptive simplicity. In his epideictic oration In what were the Athenians famous, Plutarch makes a peculiar argument for the primacy of the city's excellence in military affairs over cultural matters. ${ }^{18}$ His line of reasoning might strike one as convoluted yet several of his specific references to cultural pro-

\footnotetext{
17 See for instance Steiner (1993) 159-180; Athanassaki (2009), (2012) 134-157; Kurke (2013) 123-170.

18 De glor. Ath.346-347.
} 
duction, and especially to the verbal and visual arts, are particularly interesting. After a rather lengthy description of the battle of Mantineia and the critical role of the Athenians in its outcome, Plutarch comments on the masterful way in which the painter Euphranor captured the fervor and vehemence of this famous battle. It is in this context that the Simonidean statement is brought up. 'Simonides calls painting silent poetry and poetry painting that speaks', Plutarch says. ${ }^{19}$ Two sets of loosely interrelated comments follow. The first refers to the different temporal registers in pictorial and verbal narratives, for painters demonstrate actions as taking place at present while verbal arts narrate them as having taken place in the past. The second, somewhat lengthier, distinguishes the different media of the two arts (colors and shapes as opposed to words and phrasing) but nonetheless ends up emphasizing their ultimate shared aim: vividness, enargeia, a key concept in Greek critical thought, now explicitly attributed to Thucydides as Plutarch shifts his focus onto the historian's ability to turn listeners into viewers. Detailed examples from Thucydides' vivid descriptions of the battle of Pylos and of the Sicilian expedition bring this section of Plutarch's epideixis full circle.

Interestingly, the almost symmetrical arrangement of the passage, with the battles at the outer rims and with Euphranor and Thucydides praised respectively for their pictorial and verbal vividness in the two inner ones, puts the Simonidean statement regarding the relationship between painting and poetry right at the center of this section. This neat concentric structure makes clearer the underlying associations between center and inner rims on either side. On the one side visual virtuosity, that of Euphranor, is praised for capturing mental states that are primarily the domain of discursive modes; on the other side verbal virtuosity, that of Thucydides, is praised for triggering human faculties that are primarily the domain of sense perception. If our reading between the lines is fair, the deep structure of this section reveals implicit and far more interesting aspects concerning the relationship between poetry and painting than those explicitly mentioned by Plutarch in his rather perfunctory exegesis of the Simonidean phrase.

We will probably never learn whether, when articulating his famous statement about the two arts, Simonides indeed had in mind their different ways of developing synergies between sense perception and mental function. Yet the possibility that this statement had roots in the poet's deeper involvement with the arts and their experiential potential fits well the wide-ranging intellectual profile that was attributed to him in antiquity, for he was identified 
and acknowledged as sophos. ${ }^{20}$ Furthermore, it is important to consider the possible relationship between this statement and the specific type of poetry Simonides was actually composing. How would the various lyric genres in which he was engaged prompt such a statement about the relationship between poetry and painting?

One aspect that arises immediately is the way in which the finite space of a painting and the limited length of a melic poem urge both painter and lyric poet to zoom in on individual scenes that are carefully selected from a much longer narrative sequence of the type found in epic-style accounts. In other words, provided that such endeavors in painting are meant to-or can-be enjoyed as self-standing images (i.e. either they are not physically juxtaposed with other paintings with which they are supposed to form a narrative cluster or they can nevertheless be appreciated as independent wholes), painters and melic poets stand on common ground when considering their otherwise diverse media. ${ }^{21}$

Once this common ground is established, Simonides' extant poetry can indeed provide some insights into the manner in which the lyric poet might have been contemplating and experimenting with the interrelation between mental and sensory channels in the apprehension of verbal and visual arts. The twenty-seven-line segment of the Simonidean poem quoted by Dionysius of Halicarnassus and often identified as 'Danae's lament' is a particularly interesting instance of the way in which sensory, and especially visual, markers are ingrained in the remarkably affective language of Danae's words while her infant, Perseus, is sleeping. ${ }^{22}$ Staged by the poet as she is being tossed about in a chest on the rough sea, Danae utters a monologue dense with descriptive terms that would sound unsuitable in the mouth of a horrified mother doomed to death, were they not so intricately woven into the texture of the poem. While addressing the sleeping infant she refers to the darkness of the night and to the dark-blue murk into which they were forced while a hint of glowing light is suggested by her reference to the brazen bolts of the chest. ${ }^{23}$ Two additional sensory registers, touch and hearing, are subtly elicited in the next four lines, while Danae comments on Perseus' lack of awareness: he does not sense the sea-spray tossed over his hair by the waves and he does not hear

\footnotetext{
20 For this aspect of Simonides' profile see especially Xenophon's Hiero.

21 For painted scenes juxtaposed to one another in a narrative sequence see for instance Pausanias' descriptions of the paintings of Polygnotus in the Cnidian Lesche in Delphi $(10.25-31)$.

22 PMG 543.

23 On the diction and dramatic effect of the poem see Rosenmeyer (1991). On other aspects of the poem's visual references see for instance the insights in Carson (1999) 45-62.
} 
the sound of the wind. A reference to the purple blanket covering the infant and to his beautiful face completes her description while, at the same time, spotlighting Simonides' complete lack of interest in a realistic portrayal of a frightened mother enclosed in a dark chest in the middle of the sea. For how would she see the purple color and the beauty of the infant's face in the gloomy dark, let alone comment on them while on the verge of sinking?

In other words, Danae's emotive yet highly artificial first-person lament-like lullaby is an outstanding instantiation of a speaking painting. The carefully distributed tonalities of darkness, brightness, and color in her speech, her comment on the beauty of sleeping Perseus' face, her references to the saltspray of the waves over his hair and to the sound of the wind are all typical examples of a successful ekphrastic discourse that centers on vision while synaesthetically awakening the totality of the senses, in this case touch and hearing. A number of surviving vase paintings indicate that Danae with Perseus in the wooden chest was a favorite pictorial subject and it is therefore most probable that it was also depicted in wall-painting-or else that it could be easily imagined as such - where the potential for nuanced shading and color was considerably greater. ${ }^{24}$

Ekphrasis, more or less defined as 'descriptive language that brings what is portrayed clearly before the sight' does not seem to appear as a term before the first century $\mathrm{AD}$, and it does so then in the quite restrictive educational context of the progymnasmata, rhetorical textbooks for schoolboys. ${ }^{25}$ Yet the fundamental attributes of ekphrasis are present throughout archaic, classical, Hellenistic, and certainly imperial, literature and the models of its descriptive strategies and ramifications too many and too diverse to be put into a brief definition. By using the term ekphrastic discourse instead of ekphrasis I wish to refer to the widest possible range of verbal manipulations of the visual, which would include varying modes and ratios of descriptive and interpretive elements, in or outside longer narratives. If ekphrastic occurrences are considered this way, then lyric poetry has much to offer to its study and the present volume makes several suggestions in this direction.

Our approach so far indicates that Simonides might have been instrumental in thinking about, and experimenting with, the multiple ways in which descriptive language can enhance the emotional impact of lyric while at the same time enriching the visual imaginary of an audience that was probably encouraged to recall or imagine a painted image of Danae while listening to her words.

24 See LIMC vol. III.2 s.v. Danae.

25 Theon, Prog. p. 118 Spengel $=66$ Patillon. See Kennedy (2003) 45. 
The other context in which Plutarch quotes the Simonidean statement is in the last section of his Table-Talk (747-748) where two boys, among a group of several, excel in their dance performance and are asked by the sympotic participants to perform a pas de deux with alternating movements, for which

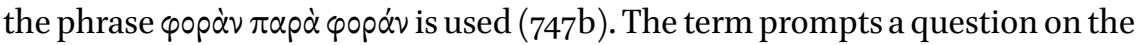
part of Thrasybulus and a long answer by the Athenian philosopher Ammonius, who undertakes to clarify the relationship between dancing movement (phora) and dancing posture (schêma) as well as the role of a third component in dance, that of pointing (deixis). It is in this broader context that the Simonidean statement concerning the relationship between poetry and painting is brought up: 'One can transfer Simonides' saying from painting to dancing' Ammonius says. 'For dance can rightly be called silent poetry and poetry speaking dance whereas there seems to be nothing from painting in poetry or from poetry in painting, nor does either art make any use whatsoever of the other; on the contrary, dancing and poetry are fully associated and the one involves the other.'26 Thus in Table-Talk the Simonidean statement is brought up only to be dismissed, yet the example Ammonius provides in order to demonstrate the deeper synergy between poetry and dance comes from another lyric poet, possibly Pindar. ${ }^{27}$

One might want to question Ammonius' (or Plutarch's own) understanding of the Simonidean phrase. For instance, his assertion that there is nothing in poetry from painting or in painting from poetry appears to be quite tenuous if one considers the vast array of themes that have been the common property of both poetry and painting throughout the Greek world and that must have cross-fertilized both the shaping and re-shaping of verbal and pictorial narratives respectively and the audiences' perception and imagination. This serious pitfall aside, however, Ammonius' juxtaposition and contrasting of two major visual arts, painting and dance, is too suggestive to pass over. Given Ammonius' (and, of course, Plutarch's) most likely familiarity with earlier discourses of verbal and art criticism lost to us, one is prompted to wonder if the otherwise awkwardly articulated comparison between the two visual arts in their relationship to poetry, with its clearly agonistic overtone, is in fact echoing views that were originally expressed by, and perhaps exchanged between, first-rate lyric poets of the late archaic and early classical period.

26 Quaest. conv. 748a. Many thanks to Anastasios Nikolaidis for his comments on Plutarch's insights.

27 See fr. 107a Sn.-M. 
Nevertheless, the famous Simonidean statement served here as an emblematic instance of the multifaceted visuality of Greek lyric poetry. This volume offers a wide range of approaches to many aspects of this rich subject that have not thus far been explored systematically.

Lyric poetry in its relation to sculpture is extensively discussed by Lucia Athanassaki, who proposes a much deeper understanding of Bacchylides' eighteenth ode, if the dithyramb that was performed in Athens is envisioned in the imaginary foreground of the south metopes of the Athenian Treasury in Delphi. Not only do the distant metopes and the Bacchylidean poem share the same narrative sequence regarding Theseus' deeds on his way from Troizen to Athens but, according to Athanassaki, because of this specific interrelation between song and monument one can better understand the political and cultural ambience surrounding the performance of this quite distinctive dithyramb. Laura Lulli also discusses sculptural scenes, the so-called 'smaller frieze' of the altar at Pergamon, where episodes of the life of Telephus are depicted. Here as well lyric poetry proves to co-operate with sculpture, but in an almost reverse manner. Whereas Athanassaki examines the pathways through which the choral song can be envisioned as interacting with, or even enacting, the metopes in Delphi, Lulli discusses the possibility that the Pergamon altar, commissioned in later times by the Attalids, is very likely to have drawn its inspiration from a long elegy attributed to Archilochus and published by Dirk Obbink in 2005 .

Another set of contributions discusses the ways in which lyric language manipulates the visual in cases where the plastic arts do not seem to play a central role in the apprehension of the lyric composition. How does a lyric poem act upon an audience's sensory perception and cultural imaginary in such cases? Michel Briand explores the manner in which Pindar's epinician odes, especially the Olympians, activate visual imagination through strategically placed stress on a wide range of terms evoking sparkle and luminosity. Thus, according to Briand, the epinician performance is amplified and irradiated in the audience's synaesthetic apprehension of the audio-visual verbal medium. Katerina Ladianou, too, discusses the sensory network of Greek chorality as formed primarily by visual associations that are eventually enhanced synaesthetically. Her focus is on the synaesthetic potential of vision in Sappho's poetry as well as on later ekphrastic literature that elaborated on its rich sensory apparatus. Caroline Trieschnigg as well explores the dynamics of synaesthesia and especially the way acoustic stimuli enhance visualization in the parodos of Seven Against Thebes. Finally, Anton Bierl examines the complex visual network of the Cologne Sappho fragment in both its verbal texture and its ritual context while underlining the fact that lyric poetry in general, and Sappho's poetry in particular, rely heavily on visual images and 
tableaux but, unlike other genres, tend to provide a rough visual outline that audiences are prompted to fill out by means of their cultural imaginary.

The importance of the visual for a key aspect of Greek lyricism, namely its erotic subjects, is discussed by Claude Calame, Laura Swift, Vanessa Cazzato and Ippokratis Kantzios. Calame explores the way in which the amorous gaze is embedded in the verbal texture of poems by Sappho, Anacreon, and Pindar and discusses extensively its complex function and dramatic enactment in Alcman's partheneia, where visual exchanges not only among choral performers but also between the chorus and its audience intensify the seductive aspects of the performance. Swift examines the unique emphasis of parthenaic songs on the visual allure of their female performers as well as on the visual aspects of their dramatic action, a feature that she considers intrinsically connected with the genre's cultural function and with Greek attitudes towards the parthenos. Vanessa Cazzato reinterprets a fragment attributed to Praxilla ( $P M G$ 754), where the suppressed eroticism of a young woman's gaze is opposed to her erotically experienced 'down-below'. The fragment is usually associated with the figure of a hetaira in a sympotic context but Cazzato, relying partially on vase painting, proposes that we understand it as part of a wedding song. Finally, Kantzios discusses two later Anacreontic compositions that are likely to belong to the Imperial period, where the erotic gaze is mediated through two particularly stimulating ekphrastic instances, in which the speaker directs an imaginary painter on how to paint a detailed portrait of the absent beloved.

The broader field of lyric production is approached in its relationship to painting in several other contributions as well, albeit from different angles. Jesús Carruesco explores the ways in which pictorial and choreographic patterns seem to be in creative and mutually interpretive dialogue in the iconography of the Geometric (and particularly of the Late Geometric) period, on the one hand, and in archaic poetic representations of choral practices, on the other. He focuses on three types of patterns especially, which he considers fundamental to both painting and choral dance: linear, circular, and whirling. The long ekphrastic archetype of the Shield of Achilles in the eighteenth book of the Iliad with its carefully arranged descriptions of dance is key to his analysis.

Despite differences in their methods and angles, Deborah Steiner's and Gregory Jones' contributions as well highlight the importance of vase painting for the interpretation of lyric poetry, while underlining the co-operation of verbal and visual practices in the Greek cultural imaginary. Steiner discusses Archilochus frr. ${ }^{185^{-1}} 187 \mathrm{~W}$. and their reference to an animal fable. While focusing especially on the role of the monkey in the poem, Steiner examines pictorial representations of simians in Greek vases that corroborate, but also enrich, the 
understanding of the poem as a comment on sympotic decorum. Gregory Jones examines lyric skolia (songs attached to actual sympotic action) inscribed on, or simply relevant to, vase-paintings depicting sympotic scenes and sheds light on the origins and the imaginary of this under-examined but culturally vital lyric genre. The symposium is also central in the contribution of Jenny Strauss Clay who examines three compositions of the archaic period, by Alcaeus, Xenophanes and (perhaps) Theognis, and comments on their diverse verbal and visual strategies in constructing the sympotic space as the locus of material and human co-existence.

By focusing on the relationship between the visual and the verbal as well as the sensory and the mental, the present volume raises a wide range of questions concerning human perception and cultural practices. As the contributions included here indicate, Greek lyric poetry played a decisive role in the shaping of both. In that respect, the volume offers an exciting stimulus for further contemplation.

\section{Works Cited}

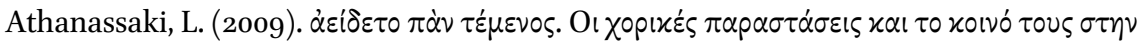

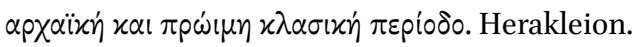

- (2012). 'Performance and reperformance: The Siphnian Treasury evoked', in P. Agócs, C. Carey, and R. Rawles (eds), Reading the Victory Ode. Cambridge: 134-157. Bowie, E. (2009). 'Wandering poets, archaic style' in Hunter and Rutherford (eds) (2009): 105-136.

Budelmann, F. (2013). 'Greek festival choruses in and out of context' in J. Billings, F. Budelmann and F. Macintosh (eds), Choruses Ancient and Modern. Oxford: 81-98. Carson, A. (1999). Economy of the Unlost. Princeton.

Csapo, E. (2004). 'The politics of the New Music', in P. Murray and P. Wilson (eds), Music and the Muses: The Culture of Mousike in the Classical Athenian City. Oxford: 207-248.

Day, J.W. (2010). Archaic Greek Epigram and Dedication: Representation and Reperformance. Cambridge and New York.

Dickinson, E. (1958). Selected Letters: edited by T.H. Johnson. Cambridge, Mass.

Driscoll, D. et al. (2015) Mapping Greek Lyric: Places, Travel, Geographical Imaginary. (http://web.stanford.edu/group/lyricmapping/linemap.html)

Fairbanks, A. (1931). Elder Philostratus, Younger Philostratus, Callistratus. Cambridge, Mass.

Gerber, D. (1999). Greek Iambic Poetry. Cambridge, Mass.

Goldhill, S. (2000). 'Placing theatre in the history of vision' in N.K. Rutter and B.A. Sparkes (eds), Word and Image in Ancient Greece. Edinburgh: 161-179. 
Hunter, R. and Rutherford, I. (2009). Wandering Poets in Ancient Greek Culture: Travel, Locality and Pan-Hellenism. Cambridge.

Kennedy, G.A. (2003). Progymnasmata: Greek Textbooks of Prose Composition and Rhetoric. Atlanta.

Kowalzig, B. (2007). Singing for the Gods: Performances of Myth and Ritual in Archaic and Classical Greece. Oxford.

Kurke, L. (1991). The Traffic in Praise: Pindar and the Poetics of Social Economy. Ithaca and London.

- (2013). 'Imagining chorality: Wonder, Plato's puppets, and moving statues' in A.-E. Peponi (ed.) Performance and Culture in Plato's Laws. Cambridge: 123-170.

LeVen, P. (2014). The Many-headed Muse: Tradition and Innovation in Late Classical Greek Lyric Poetry. Cambridge.

Morgan, K. (2015). Pindar and the Construction of Syracusan Monarchy in the Fifth Century B.c. Oxford.

Nagy, G. (1990). Pindar's Homer: The Lyric Possession of an Epic Past. Baltimore and London.

Peponi, A.-E. (2004). 'Initiating the viewer: Deixis and visual perception in Alcman's lyric drama'. Arethusa 37-3: 295-316.

— (2015). 'Dance and aesthetic perception' in P. Destrée and P. Murray (eds), $A$ Companion to Ancient Aesthetics. Malden, Mass.: 204-217.

Power, T. (2010). The Culture of Kitharôidia. Washington, DC.

Rosenmeyer, P. (1991) 'Simonides' Danae fragment reconsidered'. Arethusa 24.1: 5-29.

Rutherford, I. (2013). State Pilgrims and Sacred Observers in Ancient Greece. A Study of Theôria and Theôroi. Cambridge.

Seaford, R. (1996). Euripides' Bacchae with an Introduction, Translation and Commentary. Warminster.

Steiner, D. (1993). 'Pindar's "oggetti parlanti”'. HSCPh 95: 159-180.

Svenbro, J. (1993) Phrasikleia: An Anthropology of Reading in Ancient Greece. Trans. J. Lloyd. Ithaca and London. 